\title{
Vector-borne nematodes, emerging parasites in Finnish cervids
}

\author{
Sauli Laaksonen*, Antti Oksanen \\ From Parasite infections of domestic animals in the Nordic countries - emerging threats and challenges. \\ The 22nd Symposium of the Nordic Committee for Veterinary Scientific Cooperation (NKVet) \\ Helsinki, Finland. 7-9 September 2008
}

\section{Summary}

There is a growing body of literature documenting the expansion of emerging parasites to sub-arctic areas. The potential impact of global warming on shifts in the spatiotemporal distribution and transmission dynamics of vector-borne diseases in domesticated and wild ungulates may be remarkable [1]. Recent Finnish studies have revealed an array of Filarioid nematodes and associated diseases that appear to be emerging in northern ungulates [2-4].

Members of the genus Setaria (Filarioidea: Onchocercidae) are found in the abdominal cavities of artiodactyls (especially Bovidae), equids and hyracoids. All produce microfilariae which are present in host blood [5], and known vectors are haematophagous mosquitoes (Culicidae spp) and horn flies (Haematobia spp.) [6].

The Filarioid nematode Setaria tundra was first described in semi-domesticated reindeer (Rangifer tarandus tarandus) in Arkhangelsk area, Russia [7]. Setaria infections appear to have emerged in Scandinavian reindeer not later than in the 1960's. In 1973, S. tundra was observed for the first time in northern Norway where there was an outbreak of peritonitis in reindeer, as there was in Sweden, too. Also in 1973, tens of thousands of reindeer died in the northern part of the Finnish reindeer husbandry area. Severe peritonitis and large numbers of Setaria worms were commonly found. Following this, the incidence of Setaria in reindeer in Scandinavia diminished.

According to meat inspection data and clinical reports from practising veterinarians, the latest outbreak of peritonitis in reindeer started in 2003 in the southern and middle part of the Finnish reindeer herding area. In the province of Oulu, the proportion of reindeer viscerae condemned in meat inspection due to parasitic lesions

Finnish Food Safety Authority Evira, Fish and Wildlife Health Research Unit, P.O. Box 517, Fl-90101 Oulu, Finland increased from $4.9 \%$ in 2001 to $47 \%$ in 2004 and in Lapland from $1.4 \%$ in 2001 to $43 \%$ in 2006 . The focus of the outbreak moved approximately $100 \mathrm{~km}$ northwards yearly so that in 2005 only the reindeer in the northernmost small part of Finland (Upper Lapland) were free of changes. In the same time the outbreak seems to have settled in the southern area. [2].

The causative agent was recognized both morphologically and molecular biologically as $S$. tundra. DNA sequence of $S$. tundra parasitising reindeer in North Finland was deposited in GenBank under accession number DQ097309. [2,3].

The habitus of reindeer calves heavily infected with $S$. tundra expressed decreased welfare; low body condition and undeveloped winter fur coat. The meat inspection findings of peritonitic reindeer carcasses included ascites fluid, green fibrin deposits, adhesions and live and dead S. tundra nematodes. Histopathologically, changes indicated granulomatous peritonitis with lymphoplasmacytic and eosinophilic infiltration. No specific bacterial growth was found. No significant impact on meat $\mathrm{pH}$ values nor on organoleptic evaluation of meat was found. There was a significant positive correlation between worm count and the degree of peritonitis and a negative correlation between the degree of peritonitis and back fat layer [2]. Earlier, Setaria yehi has been associated with low grade chronic peritonitis in Alaskan reindeer [8] and S. tundra with mild to severe peritonitis together with Corynebacterium sp. in Swedish reindeer [9]. Our studies revealed that $S$. tundra can act as a significant pathogen for reindeer, which was evident at both ante and postmortem inspection and in histological examination.

In order to monitor the S. tundra parasite dynamics in nature, parasite samples from wild cervids has also been collected [2]. In moose (Alces alces), the most abundant wild cervid in the reindeer herding area, only few cases 
of pre adult encapsulated $S$. tundra nematodes on the surface of the liver, but no peritonitis, were seen.The moose was evidently not a suitable host reservoir for the present $S$. tundra haplotype. The moose population in northern Finland peaked in the years 2004 and 2005. There is a previous report of a peritonitis outbreak in moose in Finnish Lapland in 1989 associated with Setaria sp. nematodes [10]. The parasite was genetically identified as another haplotype of S. tundra. Although this earlier outbreak took place within the reindeer husbandry area, no reports on associated increased morbidity in reindeer exist.

According to our studies it is possible that the high percentage of the Kainuu population of wild forest reindeer (Rangifer tarandus fennicus) with signs of peritonitis caused by $S$. tundra (62\% of 34 animals examined) [2] is associated with the decrease of the population [11] from 1700 individuals in 2001 to 1000 in 2005.

Two roe deer (Capreolus capreolus) examined fresh in the field had S. tundra nematodes in abdomen but no signs of peritonitis. According to our studies, the roe deer seems a capable host and asymptomatic carrier for $S$. tundra. This conclusion is supported by the first $S$. tundra appearance in Scandinavia in the early 1970's [2] simultaneously with the invasion of the roe deer to North Scandinavia [12]. Further, there were minor nucleotide differences between the reindeer $S$. tundra sequence (648 bp) and that from roe deer parasites in Italy (GenBank AJ544874) [13]. In the consideration of reservoir host capacity of roe deer it is worth noting that especially young male roe deer can migrate hundreds of kilometres from their birthplace [14].

Our studies have revealed that S. tundra can have a significant pathogenic influence on the health of reindeer, and cause outbreaks also in moose population [10] and may further have consequences to cervid population dynamics.

The S. tundra outbreak in Sweden in 1973 was associated with unusually warm weather and appearance of larger than usual numbers of mosquitoes and gnats [9]. The summers 1972 and 1973 were also very warm in Finland, as were 2002 and 2003 (Finnish Meteorological Institute data, personal communication S. Nikander 2004). Mosquitoes are considered vectors for S. tundra, but the life cycle in vectors is poorly understood

Climate change is predicted to increase insect activity and thus promote vector-borne Filarioid nematodes' emerge to North and becoming a threat to the wellbeing of arctic ungulates. Especially mosquito-borne diseases are among those diseases most sensitive to climate because climate change would directly affect disease transmission by shifting the vector's geographic range and increasing reproductive and biting rates and by shortening the pathogen incubation period [15].
Our research group has studied the invasion and reservoirs of S. tundra in Finnish cervid populations, which studies we shortly review in this paper. We highlight the possibility that vector borne parasites may, by the impact of global climate change, further have consequences to wild and domestic ungulates. The study revealed the absence of baseline knowledge concerning temporal parasitic biodiversity in cervids at high latitudes. Therefore it is important to gain knowledge about these parasites' ecology, dynamics, and the impact on man and animal health.

\section{Acknowledgements}

These studies were partly funded by Ministry of Agriculture and Forestry (MAKERA).

Published: 13 October 2010

\section{References}

1. Hoberg EP, Polley L, Jenkins EJ, Kutz SJ, Veitch AM, Elkin BT: Integrated approaches and empirical models for investigation of parasitic diseases in northern wildlife. Emerg Inf Dis 2008, 14:10-17.

2. Laaksonen S, Kuusela J, Nikander S, Nylund M, Oksanen A: Parasitic peritonitis outbreak in reindeer (Rangifer tarandus tarandus) in Finland. Vet Rec 2007, 160:835-841.

3. Nikander S, Laaksonen S, Saari S, Oksanen A: The morphology of the filarioid nematode Setaria tundra, the cause of peritonitis in reindeer Rangifer tarandus. J Helminth 2007, 81:49-55.

4. Solismaa M, Laaksonen S, Nylund M, Pitkänen E, Airakorpi R, Oksanen A: Filarioid nematodes in cattle, sheep and horses in Finland. Acta Vet. Scand. 2008, 50:20.

5. Anderson RC: The Superfamily Filarioidea. Nematode parasites of vertebrates; their development and transmission CABI Publishing, New York, 2 2000, 467-529.

6. Shol VA, Drobischenko NI: Development of Setaria cervi (Rudolphi, 1819) in Cervus elaphus maral. Helminthologia (Bratislava) 1973, 14:214-246, (Russian with English abstract).

7. Rajevsky SA: Zwei bisher unbekannten Nematoden (Setarien) von Rangifer tarandus und von Cervus canadensis asiaticus. Two hitherto unknown nematodes Setaria species from Rangifer tarandus and from Cervus canadensis asiaticus Z Infekt Krank. Hyg Haustiere 1928, 35:40-52, (In German).

8. Dieterich RA, Luick JR: The occurrence of Setaria in reindeer. J Wild Dis 1971, 7:242-245.

9. Rehbinder C, Christensson D, Glatthard V: Parasitic granulomas in reindeer. A histopathological, parasitological and bacteriological study. Nordisk veterinaermedicin 1975, 27:499-507.

10. Nygren T: Riistantutkimusosaston tiedote. Bulletin of Finnish Game and Fisheries Institute 1990, 104, (in Finnish).

11. Kojola I: Petojen vaikutus metsäpeurakannoissa. Suomen Riista 2007, 53:42-48, (in Finnish).

12. Haugerud RE: Rådyret vandrer mot nord. Ottar 1989, 5:31-36, (in Norwegian).

13. Casiraghi M, Bain O, Guerro R, Martin C, Pocacqua V, Gardner SL, Franceshi A, Bandi C: Mapping the presence of Wolbachia pipientis on the phylogeny of filarial nematodes: evidence for symbiont loss during evolution. International I Parasit 2004, 34:191-203.

14. Cederlund G, Liber O: in Rådjuret, viltet, ekologin och jakten. Almqvist and Wiksell Tryckeri, Uppsala 1995, 113-117, (in Swedish).

15. Patz JA, Epstein PR, Burke TA, Balbus JM: Global climate change and emerging infectious diseases. JAMA 1996, 275:217-23.

\section{doi:10.1186/1751-0147-52-S1-S3}

Cite this article as: Laaksonen and Oksanen: Vector-borne nematodes, emerging parasites in Finnish cervids. Acta Veterinaria Scandinavica 2010 52(Suppl 1):S3. 